\title{
Relationship between diurnal grazing time and herbage intake in dairy cows in rotational grazing
}

\author{
Inter-relação entre o tempo de pastejo diurno e o consumo de forragem em vacas leiteiras \\ em pastejo rotativo
}

\author{
Henrique Mendonça Nunes Ribeiro Filho ${ }^{*}$ Elena Apezteguia Setelich ${ }^{\mathrm{II}}$ Steben Crestani ${ }^{\mathrm{I}}$ \\ Kamila Maciel Dias ${ }^{\mathrm{I}}$ Carolina Mantovani ${ }^{\mathrm{II}}$ Joana Valenti ${ }^{\mathrm{III}}$
}

\section{- NOTE -}

\begin{abstract}
The aim of this study was describe the relationship between grazing time and herbage intake and identify tools to grazing management of dairy cows grazing Italian ryegrass (Lolium multiflorum Lam.) on a rotational grazing method. Six dairy cows in mid-lactation period were allowed to graze paddocks during three grazing cycles. During each cycle cows grazed two paddocks with 9 days of occupation by paddock and an herbage allowance of $30 \mathrm{~kg} D M$ cow $^{-1}$ day $^{-1}$. Measurements were made in the last 9 days of each period and during intervals between cycles cows grazed an adjacent area with a mixed of temperate species. It was compared three grazing cycles and cows eating similar herbage amount with different daily grazing time. Independently of herbage intake, daily grazing time increased $12 \mathrm{~min}$ by $\mathrm{cm}$ of the reduction on leaf height. Reductions on efficiency to graze are clearly associated to structural traits of canopy as proximity to ground level and stems + pseudo-stems content on the graze layer. In conclusion, under rotational grazing, daily grazing time is strongly associated with leaf height in the grazing layer, but it is not a good indicator of DM herbage intake. Structural traits of canopy are clearly associated with efficiency to graze, independently of daily herbage intake.
\end{abstract}

Key words: ingestive behaviour, Lolium multiflorum Lam., sward structure.

\section{RESUMO}

Objetivou-se descrever a relação entre o tempo de pastejo e o consumo de forragem e identificar possíveis indicadores de manejo para vacas leiteiras em pastos de azevém (Lolium multiflorum Lam.) no método rotativo. Foram utilizadas seis vacas leiteiras no terço médio de lactação durante três ciclos de pastejo. Em cada ciclo, os animais tiveram acesso a dois piquetes com nove dias de ocupação e oferta de forragem de $30 \mathrm{~kg} \mathrm{MS} \mathrm{vaca}^{-1}$ dia $^{-1}$. As medidas foram realizadas nos últimos nove dias de cada ciclo e, nos intervalos entre ciclos, os animais permaneceram em área adjacente com acesso a uma mistura de espécies forrageiras de clima temperado. Comparando os três ciclos, foi possível observar que as vacas obtiveram semelhante consumo de forragem com diferentes tempos de pastejo diário. Independente da quantidade de forragem ingerida, o tempo de pastejo diário aumentou $12 \mathrm{~min}$ por $\mathrm{cm}$ de redução na altura residual de lâminas foliares $e$ reduções na eficiência de pastejo foram claramente associadas a características estruturais da pastagem, como, a proximidade ao solo e a proporção de colmos + pseudocolmos no estrato pastejado. Em conclusão, sob pastejo rotativo, o tempo de pastejo está intimamente associado com a altura residual de folhas, mas não é um bom indicador do consumo de forragem. As características estruturais do pasto são claramente associadas à eficiência de pastejo, independente do consumo diário de forragem.

Palavras-chave: comportamento ingestivo, estrutura do dossel, Lolium multiflorum Lam.

The effects of sward structure on short term foraging behavior (i.e. instantaneous intake rate - IIR) in domestic herbivores has been studied by many authors (ORR et al., 2004; BENVENUTTI et al., 2009). However, relationships between sward condition and dairy cows' short term adaptations cannot be used to predict daily herbage intake without understanding the factors that control daily grazing time (PENNING et al.,

'Programa de Pós-graduação em Ciência Animal, Universidade do Estado de Santa Catarina (UDESC), Av. Luiz de Camões, 2090, 88520-000, Lages, SC, Brasil. E-mail: a2hrf@ cav.udesc.br. "Autor para correspondência.

IIDepartamento de Produção Animal e Alimentos, UDESC, Lages, SC, Brasil.

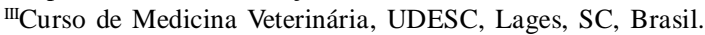


1995; PRACHE et al., 1998). The aim of this research was to study relationships between grazing time, herbage intake and sward condition as paddocks were grazed down by dairy cows in a rotational grazing method. It was verified if characteristics of herbage or ingestive behavior can be used as management tools to maximize herbage intake in dairy cows grazing Italian ryegrass.

The trial was conducted in an area of $2.1 \mathrm{ha}$ of no-tillage direct drilled ryegrass evaluated in three grazing cycles, 18 days for each cycle (9 for adaptation to ryegrass and 9 for measurement). During intervals between cycles the cows grazed an area with a mixed of perennial species (Dactilis glomerata, Festuca arundinacea and Trifolium repens) receiving $2 \mathrm{~kg}$ of ground corn after each milking. Six Holstein cows with $160 \pm 162$ days of lactation, $19.3 \pm 2.2 \mathrm{~kg}$ day $^{-1}$ of milk production and $472 \pm 39.1 \mathrm{~kg}$ body weight were evaluated. The pastures were grazed in a rotational method, with $30 \mathrm{~kg}$ of herbage allowance of DM cow ${ }^{-1} \mathrm{day}^{-1}$ and an occupation period of 9 days. The long term of occupation was necessary to identify if the moment when herbage intake start to decrease was a function of sward characteristics and/or time spent to graze. Cows assessed the paddocks when sward height was higher than $20 \mathrm{~cm}$ and the paddock area was adjusted accordingly to current biomass. During experimental cycles cows did not received concentrate supplementation.

The biomass was quantified by the ratio between the compressed height - measured with a rising plate meter (Filip's folding plate pasture meter ${ }^{\circledR}$, Jenquip company, New Zealand) - and the DM amount in the disc diameter $\left(0.1 \mathrm{~m}^{2}\right)$. Therefore, regression equations were built to estimate the current biomass $\left(\mathrm{kg} \mathrm{DM} \mathrm{ha}^{-1}\right)$ depending on the sward height $(\mathrm{cm})$. The height pattern of tiller and leaf blades was measured on days 1, 3, 5, 7 and 9 , with a ruler, on 100 units marked with telephone wires prior to the grazing.

The individual herbage intake was estimated by the fecal output quantification and by the digestibility coefficient of the herbage intake. Fecal output was estimated with an external indicator (chromium oxide, $\mathrm{Cr}_{2} \mathrm{O}_{3}$ ), regarding fecal recovery rate of $\mathrm{Cr}_{2} \mathrm{O}_{3}$ as same as 0.85 (RIBEIRO FILHO et al., 2007). The indicator was daily provided for each cow through $200 \mathrm{~g}$ of concentrated pelleted containing $0.5 \%$ of $\mathrm{Cr}_{2} \mathrm{O}_{3}$, from the first until the last day of each experimental period, after each milking. The use of low levels of $\mathrm{Cr}_{2} \mathrm{O}_{3}$ in a concentrate food was described by RIBEIRO FILHO et al. (2007). Field faeces samples were collected once a day in the morning $(8: 00 \mathrm{~h})$. The content of $\mathrm{Cr}_{2} \mathrm{O}_{3}$ in faeces was quantified by atomic absorption spectrophotometry (WILLIAMS et al., 1962) and the organic matter digestibility of herbage intake was estimated by faeces rate indicators as described by RIBEIRO FILHO et al. (2003). Cows were milked at 07:30h and $16: 30 \mathrm{~h}$ and the grazing time during the vigil period (from the sunrise until the end of the grazing which was performed after the afternoon milking) was visually evaluated, each 10 minutes (PENNING, 2004) during the same days in which canopy height measurements were performed. Grazing activities was not observed at night.

All data were analyzed by regression analysis. In each case, the best significant model explaining plotted data was tested, taking into consideration the values of standard error deviation (s.e.d.) and adjusted $\mathrm{R}^{2}$. Quadratic models were compared by inflexions points and differences among linear regressions were tested and deviation between regression coefficients (b) by two-tailed t test (calculated $\mathrm{t}=\mathrm{b} / \mathrm{b}$ pattern error) was analyzed. The analysis was performed using GraphPad Prism software, version 4.0, Windows, GraphPad Software, San Diego, California, USA.

In the first cycle daily herbage intake decreased linearly $(\mathrm{P}<0.05)$ as a function of grazing time $\left(-0.04 \mathrm{~kg} \mathrm{DM} \mathrm{min}{ }^{-1} ; \mathrm{R}^{2}=0.90\right.$; s.e.d $\left.=2.8\right)$, but in the second and third cycles, increases in time spent to graze was not associate to reductions in herbage intake (slope $=\mathrm{P}>0,05)($ Figure 1). The herbage intake as a function of occupation day $\left(\mathrm{R}^{2}=0.85-0.93\right.$; s.e.d $=0.53$ $0.81)$ and leaf height $\left(\mathrm{R}^{2}=0.51-0.87\right.$; s.e.d $\left.=0.97-1.61\right)$ was better adjusted by a quadratic model, independently of grazing cycle. Reduction on herbage intake began at sixth day of occupation, when the leaf height decreased to a value lower than $100 \mathrm{~mm}$. Besides, reductions on leaf height had the same impact on grazing time, independently of grazing cycle, with a similar regression slope (on average $-12 \mathrm{~min} \mathrm{~cm}^{-1}$ of leaf height) $\left(\mathrm{R}^{2}=0.80-0.97\right.$; s.e.d $\left.=11.4-28.6\right)$.

The lower time spent to graze when sward leaf height was higher than $100 \mathrm{~mm}$ highlights that cows grazing pastures with better leaves accessibility grazed faster and for a shorter grazing time in order to get the same herbage amount (ORR et al., 2004; GREGORINI et al., 2009). On the other hand, at the end of grazing cycle cows needed to graze for a longer period of time, probably to compensate the reduction on instantaneous intake rate (IIR), which happened with changes in sward condition as paddocks were being grazed down (BARRETT et al., 2001; BENVENUTTI et 


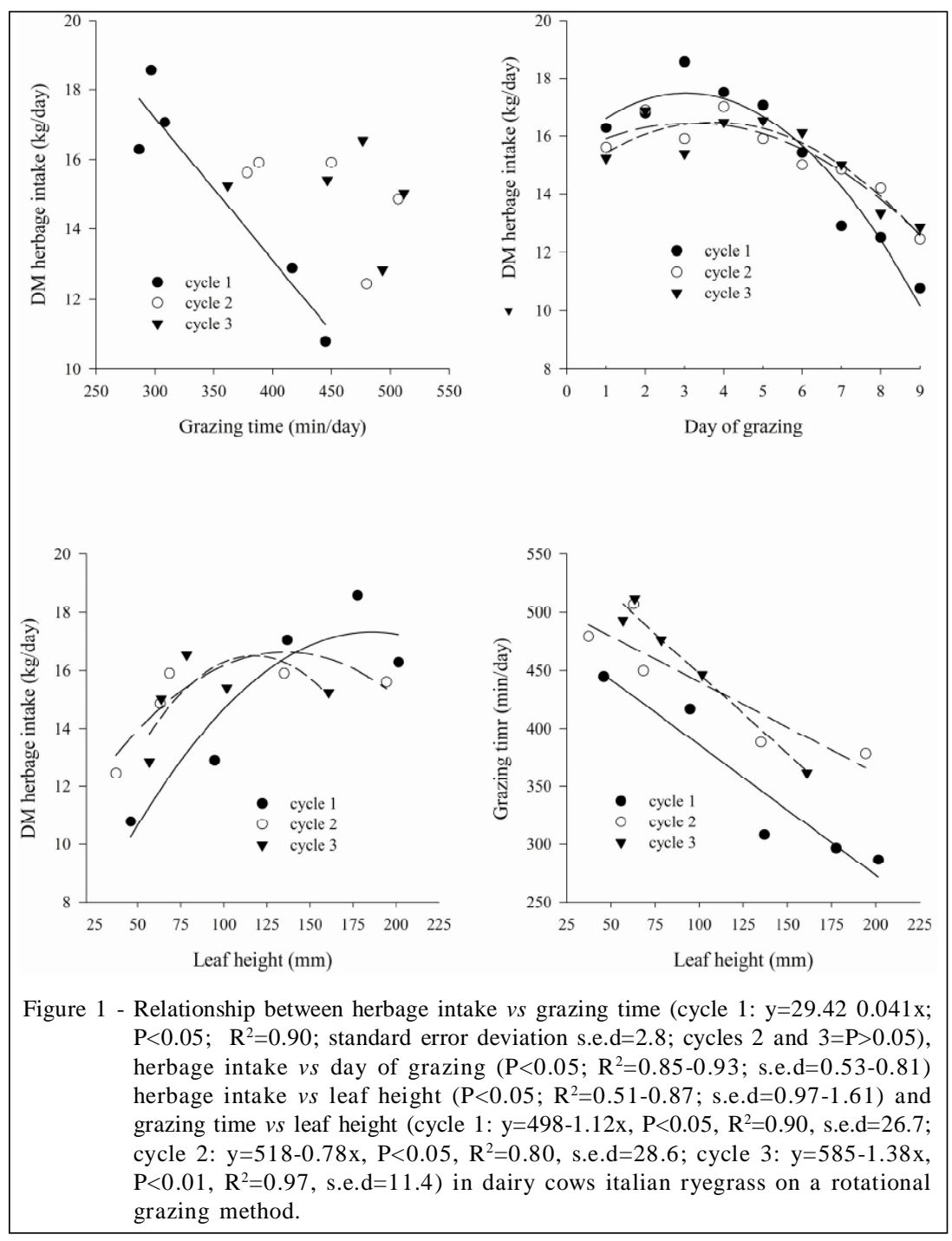

al., 2009). This reductions can be associated to depressing both, bite size and bite rate, (DRESCHER et al., 2006) due to a presence of physical barrier to defoliation (i.e, stems and pseudo-stems) (PRACHE \& PEYRAUD, 1997) or proximity to ground level (RIBEIRO FILHO et al., 2005).

At the end of occupation period of first cycle, cows spent around $400 \mathrm{~min}^{-1 a y^{-1}}$ to graze and it was not enough to compensate the reductions on IIR and the decreased daily herbage intake. Nevertheless, in the $2^{\text {nd }}$ and $3^{\text {rd }}$ cycles, cows grazed around 500 $\mathrm{min} \mathrm{day}^{-1}$ and reductions on herbage intake was not clearly a function of higher time spent to graze. This evidenced that the impact of grazing time as a mechanism to compensate reductions on IIR depends on sward condition. So, in the first cycle, IIR reductions seems to be more associated to ground proximity, because differences between pre and post canopy height were much higher than on second and third cycles (pregrazing tiller height: cycle $1=26 \mathrm{~cm}$, cycle $2=41 \mathrm{~cm}$ and cycle $3=39 \mathrm{~cm}$; post-grazing tiller height: cycle $1=$ $9.5 \mathrm{~cm}$, cycle $2=14 \mathrm{~cm}$ and cycle $3=17 \mathrm{~cm}$ ). In the other hand, at second and third cycles, reductions on IIR seems to be more associate to a higher proportion of pseudo-stems in the grazing layer and higher postgrazing pseudo-stems height compared with first cycle (pre-grazing stems + pseudo-stems proportion: cycle 1 $=38 \%$; cycle $2=54 \%$ and cycle $3=58 \%$; post -grazing pseudo-stems heights: cycle $1=5.0 \mathrm{~cm}$, cycle $2=10 \mathrm{~cm}$; cycle $3=11.5 \mathrm{~cm}$ ).

In conclusion, under rotational grazing, daily grazing time is strongly associated with leaf height in the grazing layer, but it is not a good indicator of DM herbage intake. Independently of daily herbage intake, structural traits of canopy are clearly associated with grazing efficiency. 


\section{COMITÊ DE ÉTICA E BIOSSEGURANÇA}

Número do protocolo 1.07.06

\section{ACKNOWLEDGMENTS}

To Fundação de Amparo à Pesquisa e Inovação do Estado de Santa Catarina (FAPESC) because of the financial support in the form of scholarship to Kamila Maciel Dias.

\section{REFERENCES}

BARRETT, P.D. et al. Pattern of herbage intake rate and bite dimensions of rotationally grazed dairy cows as sward height declines. Grass and Forage Science, v.56, p.362-373, 2001. Available from: <http://onlinelibrary.wiley.com/doi/10.1046/ j. $1365-494.2001 .00286 . x / a b s t r a c t$; jsessionid $=6 \mathrm{ABC} 12 \mathrm{~A} 13625882 \mathrm{ECC} 232 \mathrm{D} 8 \mathrm{~A} 176 \mathrm{FF} 556 . \mathrm{d} 01 \mathrm{t} 02 \mathrm{>}$. Accessed: Aug 20, 2011; 20, 2008. doi: 10.1046/j.13652494.2001.00286.x.

BENVENUTTI, M.A. et al. Foraging mechanics and their outcomes for cattle grazing reproductive tropical swards 2 . Applied Animal Behaviour Science, v.113, n.1-3, p.1531, 2008. Available from: <http://www.sciencedirect.com/ science/article/pii/ S0168159107003395>. Accessed: Aug 20, 2011; 20, 2008. doi:10.1016/j.applanim.2007.10.005.

BENVENUTTI, M.A. et al. The horizontal barrier effect of stems on the foraging behaviour of cattle grazing five tropical grasses1. Livestock Science, v.126, n.1-3, p.229-238, 2009.

DRESCHER, M. et al. The role of grass stems as structural foraging deterrents and their effects on the foraging behaviour of cattle. Applied Animal Behaviour Science, v.101, n.1-2,p.1026,2006. Available from: <http://apps.webofknowledge.com/ full_record.do?product=UA\&search_mode=GeneralSearch\&qid=3 $\&$ SID $=2$ CPjBEKO3GilAoIpkmo\&page $=1 \&$ doc $=1>$. Accessed: Aug 24, 2011; 20, 2008. doi: 10.1016/j.livsci.2009.07.006.

GREGORINI, P. et al. Short-term foraging dynamics of cattle grazing swards with different canopy structures. Journal of Animal Science, v.87, n.11, p.3817-3824, 2009. Available f rom : < h t t p : / a p p s.webofknowledge.com/ full_record.do?product $=U A \&$ search_mode $=$ GeneralSearch $\& q i d=4 \&$ SID $=2$ CPjBEKO3GilAoIpkmo\&page $=1 \&$ doc $=2>$. Accessed: Aug 24, 2011. doi: 10.2527/jas.2009-2094.

ORR, R.J. et al. Relationships between morphological and chemical characteristics of perennial ryegrass varieties and intake by sheep under continuous stocking management. Grass and Forage
Science, v.59, n.4, p.389-398, 2004. Available from: <http:// onlinelibrary.wiley.com/doi/10.1111/j.1365-494.2004.00440.x/ abstract;jsessionid=B2C98D187D239DA9D5241E2BE2C06FDF02t01>. Accessed: Aug 24, 2011. doi: 10.1111/j.1365-2494.2004.00440.x.

PENNING, P.D. et al. Intake and behaviour responses by sheep, in different physiological states, when grazing monocultures of grass or white clover. Applied Animal Behaviour Science, v.45, p.63-78, 1995. Available from: <http://www.sciencedirect.com/ science/article/pii/016815919500602O>. Accessed: Aug 24, 2011. doi: 10.1016/0168-1591(95)00602-O.

PENNING, P.D. Animal-based techniques for estimating herbage intake. In: PENNING, P.D. (Ed.). Herbage intake handbook. 2.ed. Reading: The British Grassland Society, 2004. p.53-94.

PRACHE, S.; PEYRAUD, J.L. Préhensibilité de l'herbe pâturée chez les bovins et les ovins. INRA Production Animal, Paris, v.10, p.377-390, 1997. Available from: < h t t p : / / a p p s. w e b o f k n o w l e d g e . c o m / full_record.do?product=UA\&search_mode $=$ GeneralSearch\&qid=9\& $\mathrm{SID}=2 \mathrm{CPjBEKO} 3$ GilAoIpkmo\&page $=1 \&$ doc $=1>$. Accessed: Aug 24, 2011.

PRACHE, S. et al. Foraging behaviour and diet selection in domestic herbivores. Annales de Zootechnie, v.47, p.335345, 1998. Available from: <http://apps.webofknowledge.com/ full_record.do?product=UA\&search_mode=GeneralSearch\&qid=11\&SID $=2 \mathrm{CPjBEKO} 3$ GilAoIpkmo\&page $=1 \&$ doc $=1>$. Accessed: Aug 24, 2011. doi: 10.1051/animres:19980502.

RIBEIRO FILHO, H.M.N. et al. Baixa dosagem de óxido de cromo para a estimativa da produção fecal em bovinos. Ciência Rural, v.38, p.2567-2573, 2008. Available from: <http:// www.scielo.br/scielo.php?script $=$ sci_arttext $\&$ pid $=$ S0 103 $84782008000900025 \& \operatorname{lng}=\mathrm{pt} \& \mathrm{nrm}=\mathrm{iso} \& \operatorname{lng}=\mathrm{pt}>$. Accessed: Aug 24, 2011. doi: 10.1590/S0103-84782008005000014.

RIBEIRO FILHO, H.M.N. et al. Herbage intake and milk yield of dairy cows grazing perennial ryegrass swards or white clover/ perennial ryegrass swards at low- and medium-herbage allowances. Animal Feed Science and Technology, v.119, p.13-27, 2005. Available from: <http://www.sciencedirect.com/ science/article/pii/S037784010400330X>. Accessed: Aug 24, 2011. doi: 10.1016/j.anifeedsci.2004.12.009.

WILLIAMS, C.H. et al. The determination of chromic oxide in faeces samples by atomic absortion spectrophotometry. Journal of Agriculture Science, v.59, p.381-385, 1962. Available from: <http://journals.cambridge.org/action/ display Abstract? fromPage $=$ online\&aid=4540568>. Accessed: Aug 24, 2011. 